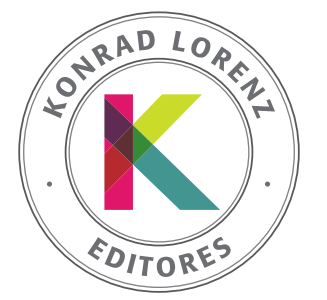

SUMA PSICOLÓGICA

http://editorial.konradlorenz.edu.co/suma-psicologica.html

\title{
Validation of the Wong and Law Emotional Intelligence Scale for Chilean managers
}

\author{
Julio César Acosta-Prado ab*, Rodrigo Arturo Zárate Torres ${ }^{c}$
}

\author{
a Universidad del Pacífico, Lima, Perú \\ b Universidad Externado de Colombia, Bogotá, Colombia \\ c Colegio de Estudios Superiores de Administración, Bogotá, Colombia
}

Received 19 July 2019; Accepted 13 January 2020

\section{KEYWORDS Emotional intelligence scale, WLEIS, Chilean managers, factor analysis}

\section{PALABRAS CLAVE}

Escala de inteligencia emocional, WLEIS, gerentes chilenos, análisis factorial

\begin{abstract}
The Wong and Law Emotional Intelligence Scale, WLEIS, is one of the most widely used instruments for measuring emotional intelligence in the world. This scale was designed for the work context and evaluates the assessment and expression of a person's emotions, the assessment and recognition of emotions in others, the regulation of a person's emotions, and the use of emotion to aid performance. However, in the Chilean context, there have been no studies on the validity of WLEIS for senior management within firms. The present study seeks to obtain evidence of validity based on WLEIS' internal structure using a sample of 100 Chilean managers. This is an instrumental type study. An exploratory and confirmatory factor analysis corroborated the dimensions of WLEIS, which presented adequate levels of reliability. The average scores in the factors were then compared according to age, sex, and level of educational. The implications of these findings are discussed in the last section.
\end{abstract}

(c) 2019 Fundación Universitaria Konrad Lorenz. This is an open access article under the CC BY-NCND license (http://creativecommons.org/licenses/bync-nd/4.0/).

\section{Validación de la Escala de Inteligencia Emocional de Wong y Law en gerentes chilenos}

Resumen La Escala de Inteligencia Emocional de Wong y Law, WLEIS, es uno de los instrumentos para la medición de la inteligencia emocional más utilizados en el mundo. Esta escala fue diseñada para el contexto laboral y evalúa la valoración y expresión de las emociones propias, valoración y reconocimiento de las emociones en otros, regulación de las propias emociones y el uso de las emociones para facilitar el desempeño. No obstante, en el contexto chileno no existen estudios sobre la validación del WLEIS en altos mandos gerenciales dentro de las empresas. El presente estudio busca obtener evidencias de validez basada en la estructura interna del WLEIS en una muestra de 100 gerentes chilenos. El estudio es de tipo instrumental. A través de un análisis factorial exploratorio y confirmatorio, se corroboraron las dimensiones de WLEIS, que presentaron niveles adecuados de fiabilidad. Luego, se compararon los puntajes

\footnotetext{
* Autor para correspondencia.

Correo electrónico: jc.acostap@up.edu.pe; julioc.acosta@uexternado.edu.co
}

http://dx.doi.org/10.14349/sumapsi.2019.v26.n2.7

0120-0534/@ 2019 Fundación Universitaria Konrad Lorenz. Este es un artículo Open Access bajo la licencia CC BY-NC-ND (http://creativecommons.org/licenses/by-nc-nd/4.0/). 
promedios en los factores según edad, género y nivel educativo. Las implicaciones de estos hallazgos son discutidas sobre la literatura existente en el campo.

(c) 2019 Fundación Universitaria Konrad Lorenz. Este es un artículo Open Access bajo la licencia CC BY-NC-ND (http://creativecommons.org/licenses/bync-nd/4.0/).

Bar-On (1997) mentions that emotional intelligence (EI) has been proposed as an important and potential construct for human resource management. Likewise, Anand and UdayaSuritan (2010) note that El empowers managers with the ability to sense what others need and want, which allows them to develop strategies to meet those needs and desires. El has been linked to individuals' personal and professional performance. Dabke (2016) claimed that various facets and components of El contribute to success and productivity in the workplace. Bar-On (1997) states that El helps employees to succeed in their jobs when they face demands and pressures.

According to Salovey and Mayer (1990), the term El is defined as a subset of social intelligence that involves the ability to monitor one's own and others' feelings, distinguish and classify them, and then use this information to guide our emotions, thoughts, and actions. In this sense, El helps to understand and value our own emotions; this helps us when using our emotions to solve our problems and regulate our behaviour.

Mayer and Salovey (1997) later redefined El as the ability to accurately perceive, appraise, and express emotions; the ability to access and/or generate feelings when they facilitate thought; the ability to understand emotions and emotional knowledge; and the ability to regulate emotions to promote emotional and intellectual growth.

Some authors (Abdullah, Omar, \& Panatik, 2015; Acosta-Prado \& Zarate, 2017; Cooper \& Sawaf, 1997; Goleman, 1996; Mayer \& Salovey, 1993, 1997; Salovey \& Mayer, 1990) reinforce the definition of $\mathrm{El}$ as a degree of ability to perceive, to interpret one's own benefit using others' emotions, and as the ability to understand and manage one's own emotions. This involves only $20 \%$ of the factors that determine success; the remaining $80 \%$ corresponds to the factors that are related to what is called El (Goleman, 1996).

As part of efforts made to agree on the definition of El, Schulte, Ree, and Carretta, (2004) mention that the inclusion of variables that are not capabilities to be able to construct El may have affected their scientific rigor as a different construct. Davies, Stankov, and Roberts (1998) described $\mathrm{El}$ as an elusive concept and also state that the measures related to El are the same used in studies of personality. Acosta-Prado, Zarate, and Pautt (2015) point out that, based on these relationships and having made several exploratory factor analyses, the El construct was weak. Mayer, Salovey, and Caruso (2000) defined El as an ability to process emotional information accurately and efficiently, including the ability to perceive, assimilate, understand, and regulate emotions. The current study uses this definition as an operational definition of El.

Recent studies show El as a variable that determines employee's performance. Dabke (2016) mentions that it has been claimed that different facets and dimensions of El have contributed to success and productivity in the workplace. Other authors state that there is a relationship between El and job performance (Acosta-Prado \& Zarate, 2017; Jordan, Ashkanasy, Härtel, \& Hooper, 2002; Law, Wong, \& Song, 2004), and others imply that there is a relationship between $\mathrm{El}$ and individual and group development (Livingstone, Nadjiwon-Foster, \& Smithers 2002).

According to Ashforth and Humphrey (1995), studies on business management suggest that there has been a relative neglect of the role played by emotions in everyday business life as this is more often attributed to a human relations perspective. The emotional can certainly alter the rational aspect of the organization. Argyris (1985) called it the great paradox of business conduct as the rational functions of a task and can be affected by emotional barriers: a manager can directly affect a company's emotional climate. Moreover, Hogan and Kaiser (2005) mention that recent research shows $65 \%$ to $75 \%$ of employees believe the worst aspect of their job is their immediate boss. This fact is more related to the undesirable qualities of managers (their personality defects) rather than the lack of desirable qualities.

Leslie and Van Velsor's study (1996) identify some unsuccessful managers' emotions: coldness, arrogance, and poor interpersonal skills. The authors mention that these emotions betray the trust of others and mean that these managers find it difficult to work with others. Similarly, Butler and Chinowsky's study (2006) identifies that the weaknesses of El are linked to interpersonal skills including lacking empathy, weak relationships, and poor social responsibility.

Several authors have studied the relationship between $\mathrm{El}$ and managers. The studies say that El helps managers to make decisions (Schwartz, 1990), articulate a vision, provide encouragement to employees, and create employee initiative (Gardner \& Stough, 2002). Also, El influences managers' behaviour through the characteristics of the tasks performed, the performance level, and the feedback processes (Fisher \& Ashkanasy, 2000; Goonan \& Stoltz, 2004), which will result in lowering employee's stress and, at the same time, increasing their job satisfaction, willingness to change, and health.

Despite the previously-mentioned studies, some managers still believe they can make employees carry out activities regardless of their emotional characteristics (Ashkanasy \& Rush, 2004). According to Smollan and Parry (2011), employees take note of how managers respond to their emotions; thus, a manager who does a good job makes it more likely that employees will share their own emotions. Managers can make employees copy the expression of their emotions (Sanchez-Burks \& Huy, 2009), which takes place through mirror neurons (Rizzolatti \& Craighero, 2004) that replicate managers' emotions (Goleman \& Boyatzis, 2008). Fullan (2001) mentions that the responsibility of future generations of managers will be El, successful social relations, and managing change.

Cartwright and Pappas (2008) state that The American Society for Training and Development claims that approximately $80 \%$ of companies are trying to identify employees' 
El to improve customer service (Cavelzani, Lee, Locatelli, Monti, \& Villamira, 2003), to increase sales, and to ensure that their managers do well internationally.

The instrument used in this research is the Emotional Intelligence Scale developed by Wong and Law (2002). It has been validated by different authors including Aslan and Erkus (2008), who conclude that this instrument could be used in leadership, management, and organizational behaviour. Based on the above, there is a consensus that El is the ability individuals have to manage emotions, and it is composed of four factors or variables that explain managers' performance (Acosta-Prado, Zarate \& Pautt, 2015; Goleman, 1996; Law, Wong, \& Song, 2004; Mayer, Salovey, \& Caruso, 2000; Salovey \& Mayer, 1990; Wong, Wong, \& Law, 2007).

Self-Emotion Appraisal. Understanding and valuing of one's own-emotions. Each person's ability to understand their deepest emotions and express them naturally.

Other's Emotion Appraisal. Understanding and valuing emotions in others. Individuals abilities to perceive and understand the emotions of people around them.

Use of Emotion. People's capacity to use their own emotions to route them towards constructive activities and personal performance.

Regulation of Emotion. People's ability to regulate their emotions, which empowers them to recover more quickly from mood swings and anxiety.

Throughout the world, psychometric studies have been carried out on the WEIS using different samples. Results have found that, by-in-large, the instrument is made up of the four originally-proposed dimensions (Carvalho, Guerrero, Chambel, \& González-Rico, 2016; El Ghoudani, Pulido-Martos, \& Lopez-Zafra, 2018; Fukuda, Saklofske, Tamaoka, \& Lim, 2012; Iliceto \& Fino, 2017; Nguyen, Nham, \& Takahashi, 2019; Pacheco, Rey, \& Sánchez-Álvarez, 2019); however, studies are scarce for Latin American (Merino Soto, Lunahuaná-Rosales, \& Pradhan, 2016). Additionally, there is a lack of knowledge regarding the psychometric properties of WLEIS with samples that involve workers in general and managers specifically. Therefore, the present study obtains evidence of validity based on the internal structure of the WLEIS for a group of Chilean managers. It also compares the WLEIS dimension scores according to the managers' sex, age, and level of education.

\section{Method}

\section{Design}

According to Ato, López, and Benavente (2013) this is an instrumental study due to the validity and revision of the psychometric properties of the Wong and Law Emotional Intelligence Scale (WLEIS).

\section{Participants}

The sample consisted of 100 Chilean managers, who were chosen due to certain characteristics such as being in charge of at least one subordinate and, working in a company in a different sector in Chile. Participants were selected through non-probability and convenience sampling. The Chilean managers chosen had similar demographic characteristics such as their age ( 8 between 21 and 25; 49 between 26 and 35; 35 between 36 and 45; and, 8 between 46 and 60), their sex (48 women, 52 men), and their education level ( 1 had secondary education; 19 did not finish university; 57 had university degrees; and, 23 had postgraduate degrees).

\section{Instrument}

The Wong and Law Emotional Intelligence Scale - WLEIS (Wong \& Law, 2002). This scale is a self-report measure composed of four dimensions and 16 items: four items for each dimension. WLEIS use an ordinal response format (7-point Likert), and participants answered agree or disagree with the affirmation presented in each item from 1 (strongly disagree) to 7 (strongly agree). The four subscales or factors are (1) Self-emotion appraisal (SEA); (2) Other's emotion appraisal (OEA); (3) Use of emotion (UOE); and, (4) Regulation of emotion (ROE).

\section{Procedure}

Management data were obtained from secondary sources including business directories available on the internet, databases from chambers of commerce, and Chilean publications during the 2017-2018 period. Managers completed the questionnaire in-person. All responses were anonymous and confidential. The information collected was tabulated in a database using a Microsoft Office Excel spreadsheet. Finally, the suitability of the database was corroborated, and no incomplete information was detected (missing values or values out of the possible range). Throughout this study, we followed the APA standards and ethical values required in research with human beings and also respected the fundamental principles of the Declaration of Helsinki including its recent updates and regulations.

\section{Data Analysis}

The analysis was executed using the $\mathrm{R}$ Statistics software, version 3.6.1 (R Core Team, 2019) supported by the base packages, tidyverse (Wickham, 2017), psych (Revelle, 2018), pacman (Rinker \& Kurkiewicz, 2017), and lavaan (Rosseel, 2012). The analysis consisted of three phases. First, we collected validity evidence based on the internal structure of the scale using the Exploratory Factor Analysis, EFA, and Confirmatory Factor Analysis, CFA (Aliaga, 2018; American Educational Research Association, American Psychological Association, \& National Council on Measurement in Education, 2014).

In the EFA, the adequacy of the polychoric correlation matrix was analysed using the Kaiser-Meyer-Olkin or KMO index (Kaiser, 1974) and Bartlett's Sphericity Test (Bartlett, 1950). The Unweighted Least Squares (ULS) method was used to estimate the factor structure. To determinate the number of factors, we used the Kaiser-Gutman rule (eigenvalues greater than 1), the scree test (Cattell, 1966), and parallel analysis (Horn, 1965). Moreover, Oblimin oblique rotation was used because the factors are highly interrelated. 
CFA was used through the Weighted Least Squares Means and Variance adjusted (WLSMV) estimation method with robust standard errors and a SS (Scaling-Shifted) scaled statistical test. In order to assess the fit of the model, we considered several indexes: the ratio between adjusted chi-square and degrees of freedom $\left(\mathrm{SS} \chi^{2} / d f\right)$, lessthan-two was seen as an adequate value; Comparative Fit Index (CFI), superior to .95 was considered as good (Keith, 2019); Tucker-Lewis Index (TLI), above 95 indicated a good fit (Keith, 2019; Schumacker \& Lomax, 2016); Root Mean Square Error of Approximation (RMSEA), with values below .06 being indicative of a good fit model (Hu \& Bentler, 1999); Standardized Root Mean Square Residual (SRMR), values lees than .08 suggest a good fit model (Hu \& Bentler, 1999; Keith, 2019).

During the second stage, the internal consistency reliability was estimated using the alpha coefficient (Cronbach, 1951; Guttman, 1945; Hoyt, 1941). To interpret reliability, we used the levels proposed by George and Mallery (2013): Unacceptable $(\alpha<.50)$, poor $(.50<\alpha<.60)$, questionable $(.60<\alpha<.70)$, acceptable $(.70<\alpha<.80)$, good $(.80<\alpha<.90)$, and excellent $(\alpha>.90)$.

Finally, we compared the mean scores in the four WLEIS factors through using the participants' sex, age groups, and educational level. For sex, Welch's $t$-test was used, and it was more robust when the homogeneity of variance was not met. Cohen's $d$ was used as a measure of the effect of size. Regarding the comparisons according to age groups and educational level, we used an analysis of variance (ANOVA) and the square omega coefficient $\left(\omega^{2}\right)$ as an estimator of the effect size.

\section{Results}

For the EFA, the index of sampling adequacy was middling $(\mathrm{KMO}=.76)$. The Bartlett's Sphericity Test showed that the correlation matrix was adequate for the factor analysis, $x^{2}(120)=583.67, p<.001$. Horn's parallel analysis and the Kaiser-Gutman rule suggests four factors, and the scree test indicates extracting one factor. An EFA (four factors) was executed for which all items have factor loadings greater than .30, except item (UOE_1). The structure found was similar to that reported by Wong \& Law (2002); however, there were differences in the items SEA_4 and UOW_1 (Table 1).

In terms of the CFA, the first model was designed based on Wong \& Law's (2002) theoretical formulation, four factors with four items each, Self-emotion appraisal (SEA_1 to SEA_4), Other's emotion appraisal (OEA_1 to OEA_4), Use of emotional (USE_1 to USE_4), and Regulation of emotion (ROE_1 to ROE_4). Model 2 was constructed based on model 1 , for which the correlation between the errors from items SEA_1 and SEA_2 was added. Model 3 was built based on model 2 and the correlation between the errors from items OEA_3 and OEA_4 was added. This model showed the best fit indices (Table 2). Additionally, Figure 1 presents the standardized coefficients for Model 3 and their standard errors.

Reliability was measured using the alpha coefficient $(\alpha)$, and a value greater than .60 was considered as an acceptable level (Nunnally \& Bernstein, 1994) during the first stages of a research. In this study, the data collected for the measured variables showed poor (UOE $=.59)$, questionable $(\mathrm{SEA}=.68$; OEA $=.66)$ and good $(\mathrm{ROE}=.82)$ internal consistency reliability according to George and Mallery (2013).
Regarding the differences in emotional intelligence factors according to participants' sex, statistically significant differences were found in Other's emotion appraisal (OEA) and Use of emotion (UOE). Both cases had a small effect size and were favourable for women (Table 3 ).

Regarding the differences in emotional intelligence factors according to the age groups of the participants, no statistically significant differences were found. This meant the effect size was null for all cases (Table 4).

Regarding the differences in the emotional intelligence factors according to participants' level of educational, no statistically significant differences were found (Table 5). However, the effect size was small for Regulation of emotion (ROE), Other's emotion appraisal (OEA), and Use of emotion (UOE), which indicated small differences among participants. Those who had postgraduate studies obtained the highest mean scores in the three factors mentioned. It is important to mention that; we did not work with the "secondary education" category because only one case was obtained.

\section{Discussion}

The main objective of this study was to obtain evidence of validity based on the WLEIS' internal structure for a group of Chilean managers as well as to compare the scores for the WLEIS dimensions according to the managers' sex, age, and educational level. Among the key findings, we found that even though the dimensions of El (Regulation of emotion; Other's emotion appraisal; Self-emotion appraisal; and Use of emotion), identified in Chilean managers were developed as a joint process that favour managers' efficient management, self-emotion appraisal has a greater influence on the other dimensions for Chilean managers. El gives Chilean managers a greater understanding of the business contexts and interpersonal relationships with collaborators.

The results of CFA provided evidence that the WLEIS shares the four-factor structure found in the original version (Wong \& Law, 2002). Additionally, the factors corresponding to the WLEIS dimensions were strongly related to each other, providing support to the proposed model that WLEIS factors are interrelated and measure different components of the same construct. In sum, the WLEIS is a reliable and valid instrument to be used in leadership, management, and organizational behaviour contexts to assess El.

For the comparisons of demographic variables, statistically significant differences were found in Other's emotion appraisal (OEA) and Use of emotion (UOE) that considered sex. With respect to age groups and educational level, no statistically significant differences were found. However, effect size was small for Regulation of emotion (ROE), Other's emotion appraisal (OEA), and Use of emotion (UOE) when considering educational level.

The main implications of the study are theoretical and practical. Theoretically, a conceptual framework was found relating to El and Chilean managers that has hardly been discussed in the literature, and this has guided and supported the objective of this research. On a practical level, contributions help company managers, especially those who work in dynamic environments, to understand how the influence of El dimensions (Regulation of emotion; Other's emotion appraisal; Self-emotion appraisal; and Use of emotion) that were identified in Chilean managers can be developed as a joint process that favour the efficient management of 
Table 1 Factor Loadings from Exploratory Factor Analysis: Communalities, Eigenvalues, and Percentages of Variance for the WLEIS Items $(N=100)$

\begin{tabular}{|c|c|c|c|c|c|}
\hline \multicolumn{6}{|c|}{ Factor loading } \\
\hline Item & ROE & OEA & SEA & UOE & Communality \\
\hline SEA_1 & -.05 & -.01 & .93 & -.03 & .79 \\
\hline SEA_2 & .19 & .01 & .52 & .16 & .50 \\
\hline SEA_3 & .19 & .13 & .46 & .02 & .44 \\
\hline SEA_4 & .16 & .30 & .00 & .26 & .31 \\
\hline OEA_1 & .16 & .57 & -.04 & -.12 & .39 \\
\hline OEA_2 & -.06 & .75 & .04 & .01 & .55 \\
\hline OEA_3 & -.01 & .43 & .01 & .21 & .30 \\
\hline OEA_4 & .07 & .31 & .02 & .22 & .24 \\
\hline UOE_1 & .00 & .29 & .10 & .27 & .27 \\
\hline UOE_2 & .25 & .07 & .00 & .38 & .30 \\
\hline UOE_3 & .12 & .15 & .22 & .45 & .50 \\
\hline UOE_4 & -.05 & .01 & .02 & .72 & .52 \\
\hline ROE_1 & .57 & .07 & .05 & .22 & .54 \\
\hline ROE_2 & .55 & .01 & .05 & .22 & .46 \\
\hline ROE_3 & .79 & -.03 & -.02 & -.07 & .57 \\
\hline ROE_4 & .59 & .17 & .09 & -.18 & .52 \\
\hline Eigenvalue & 2.18 & 1.79 & 1.68 & 1.55 & \\
\hline$\%$ of variance & 13.62 & 11.21 & 10.50 & 9.67 & \\
\hline \multicolumn{6}{|c|}{ Factor correlations } \\
\hline OEA & - & & & & \\
\hline ROE & .58 & - & & & \\
\hline SEA & .42 & .49 & - & & \\
\hline UOE & .23 & .36 & .39 & - & \\
\hline
\end{tabular}

Note. Boldface indicates the highest factor loadings. ROE = Regulation of emotion; OEA = Other's emotion appraisal; SEA = Self-emotion appraisal; UOE = Use of emotion.

Table 2 Goodness-of-Fit Indicators of the Models for the WLEIS $(N=100)$

\begin{tabular}{|c|c|c|c|c|c|c|c|}
\hline Model & $S S \chi^{2}$ & df & $\mathrm{SS} \chi^{2} / \mathrm{df}$ & $\begin{array}{l}\text { RMSEA } \\
\text { [IC 90\%] }\end{array}$ & SRMR & CFI & TLI \\
\hline Model 1 & 117.55 & 98 & 1.20 & $\begin{array}{c}.045 \\
{[.001-.072}\end{array}$ & .086 & .930 & .914 \\
\hline Model 2 & 110.71 & 97 & 1.14 & $\begin{array}{c}.038 \\
{[.001-.068}\end{array}$ & .081 & .951 & .939 \\
\hline Model 3 & 105.21 & 96 & 1.10 & $\begin{array}{c}.031 \\
{[.001-.064}\end{array}$ & .077 & .967 & .959 \\
\hline
\end{tabular}




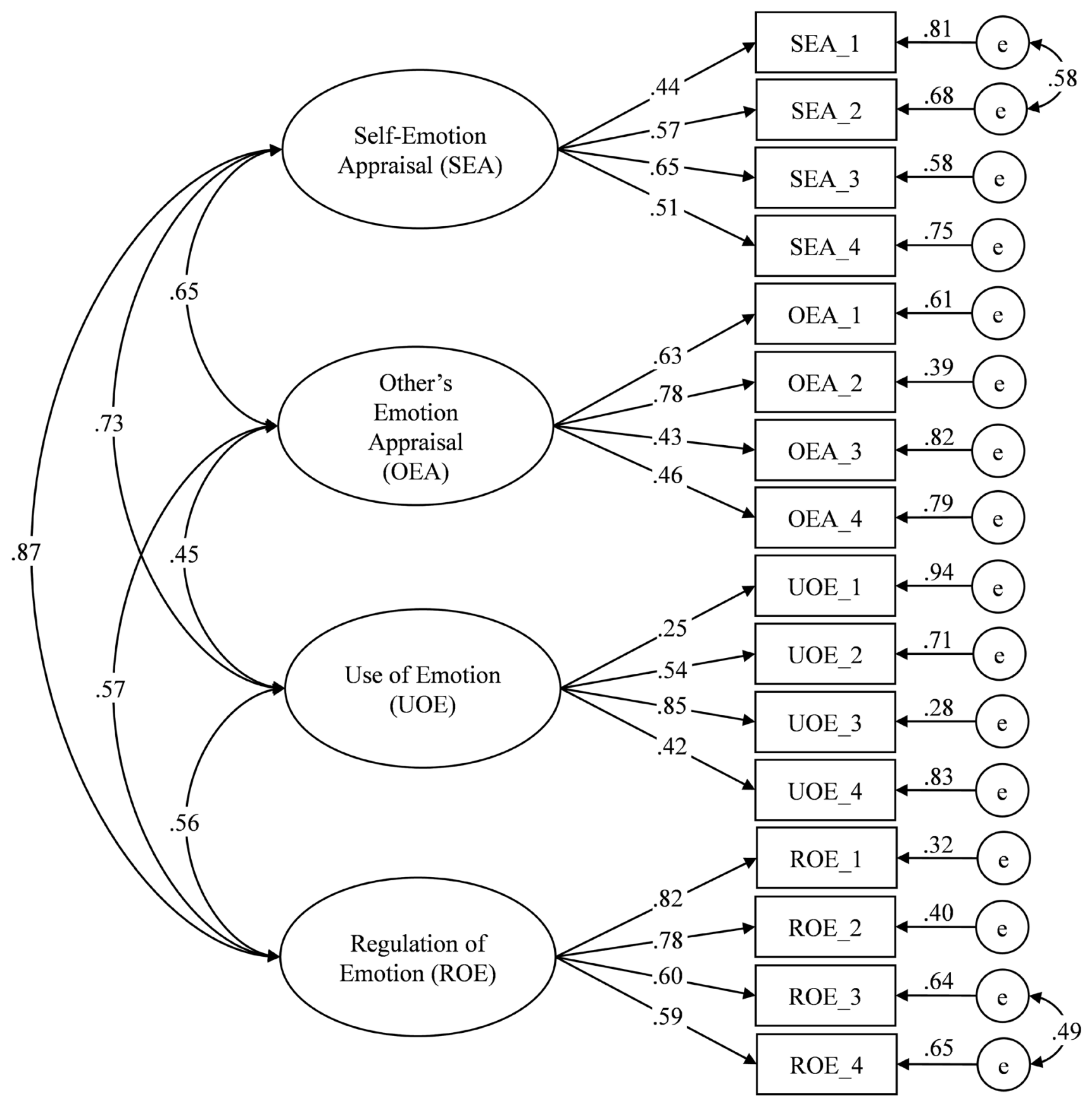

Figure 1. Standardized coefficients for Model 3 and their standard errors. Latent constructs are shown in ellipses and observed variables are shown in rectangles.

Table 3 Group differences on emotional intelligence factors according to sex

\begin{tabular}{|c|c|c|c|c|c|c|c|}
\hline \multirow[b]{2}{*}{ Variable } & \multicolumn{2}{|c|}{$\begin{array}{c}\text { Man } \\
(n=52)\end{array}$} & \multicolumn{2}{|c|}{$\begin{array}{l}\text { Woman } \\
(n=48)\end{array}$} & \multirow[b]{2}{*}{$t$} & \multirow[b]{2}{*}{$p$} & \multirow[b]{2}{*}{$d$} \\
\hline & $M$ & $D E$ & $M$ & $D E$ & & & \\
\hline SEA & 23.21 & 2.55 & 23.54 & 3.19 & 0.57 & .57 & 0.11 \\
\hline OEA & 22.21 & 3.49 & 23.46 & 2.24 & 2.14 & .04 & 0.42 \\
\hline UOE & 23.96 & 2.62 & 24.98 & 2.20 & 2.11 & .04 & 0.42 \\
\hline ROE & 22.29 & 3.26 & 22.71 & 2.97 & 0.67 & .50 & 0.13 \\
\hline
\end{tabular}

Note. SEA = Self-emotion appraisal; OEA = Other's emotion appraisal; UOE = Use of emotion; ROE = Regulation of emotion. 
Table 4 Group differences on emotional intelligence factors according to age groups

\begin{tabular}{cccccc}
\hline Variable & SS & MS & $\boldsymbol{F}$ & $\boldsymbol{p}$ & $\omega^{2}$ \\
\hline SEA & 16.27 & 5.42 & 0.65 & .58 & .00 \\
OEA & 2.92 & 0.97 & 0.10 & .96 & .00 \\
UOE & 0.51 & 0.17 & 0.03 & .00 & .00 \\
ROE & 30.11 & 10.04 & 1.03 & .00 \\
\hline
\end{tabular}

Note. SEA = Self-emotion appraisal; OEA = Other's emotion appraisal; UOE = Use of emotion; ROE = Regulation of emotion.

Table 5 Group differences regarding emotional intelligence factors according to educational level

\begin{tabular}{cccccc}
\hline Variable & SS & MS & $\boldsymbol{F}$ & \multicolumn{1}{c}{$\omega^{2}$} \\
\hline SEA & 26.21 & 13.10 & 1.60 & .21 & .01 \\
OEA & 52.55 & 26.27 & 2.99 & .06 & .04 \\
UOE & 26.24 & 13.12 & 2.21 & .12 & .02 \\
ROE & 5.50 & 2.75 & 0.28 & .76 \\
\hline
\end{tabular}

Note. SEA = Self-emotion appraisal; OEA = Other's emotion appraisal; UOE = Use of emotion; ROE = Regulation of emotion.

both understanding labour and relationships between team members.

The psychometric properties of the measuring instruments belong to the scores rather than the tests themselves. Additional studies in sectors other than those we looked at in this paper are required to find out the operation of the measurement scale. In addition, this study collected evidence regarding validity, however, the validation process involves collecting a greater amount of evidence. In this sense, evidence based on the content of the test, the relationship with other variables, and internal processes or consequences are necessary to demonstrate how solid the WLEIS is. Also, differences were found according to sex. It is, therefore, important to analyse the invariance of the measurement between men and women, as previous studies have done (Li, Saklofske, Bowden, Yan, \& Fung, 2012; Libbrecht, Beuckelaer, Lievens, \& Rockstuhl, 2014). Future studies could focus on these analyses to provide greater support to what we found.

Finally, the study shows a double contribution from the results obtained. First, it opens the social scientific debate on the theoretical-practical analysis of the implications of El for managers. Secondly, it serves as a guide to generate new lines of research that allow us to gain a greater perspective of the conditions or variables that favour the development of emotional competences in this type of sample.

\section{References}

Abdullah, I., Omar, R., \& Panatik, S.A. (2015). Famous theories surrounding emotional intelligence: A historical review. International Business Management, 9(3), 319-324.

Acosta-Prado, J. C., \& Zarate, R. A. (2017). Emotional Intelligence in Latin American

Managers: An exploratory study. Universitas Psychologica, 16(3), 1-11. http://dx.doi.org/10.11144/Javeriana.upsy16-3.eila
Acosta-Prado, J. C., Zarate, R. A., \& Pautt, G. M. (2015). Characterization of emotional intelligence in Colombian managers. Universitas Psychologica, 14(3), 815-832. http://dx.doi. org/10.11144/javeriana.upsy14-3.ceic

Aliaga, J. (2018). Psicometría: disciplina de la medición en psicología y educación. Lima: Fondo Editorial de la Universidad Inca Garcilaso de la Vega.

American Educational Research Association, American Psychological Association, \& National Council on Measurement in Education. (2014). Standards for educational and psychological testing. Washington, DC: American Educational Research Association.

Anand, R., \& UdayaSuriyan, G. (2010). Emotional intelligence and its relationship with leadership practices. International Journal of Business and Management, 5(2), 65-76.

Argyris, C. (1985). Strategy, change and defensive routines. Boston, MA: Pitman.

Ashforth, B., \& Humphrey, R. (1995). Emotion in the workplace: A reappraisal. Human Relations, 48(2), 97-125. http://dx.doi. org $/ 10.1177 / 001872679504800201$

Ashkanasy, N. M., \& Rush, S. (2004). Emotional rescue: A conversation with Neal M. Ashkanasy. Leadership in Action, 24(4), 1518. http://dx.doi.org/10.1002/lia.1078

Aslan, S., \& Erkus, A. (2008). Measurement of emotional intelligence: Validity and reliability studies of two scales. World Applied Science Journal, 4(3), 430-438.

Ato, M., López, J. J., \& Benavente, A. (2013). A classification system for research designs in psychology. Anales de Psicología, 29(3), 1038-1059. http://dx.doi.org/10.6018/analesps.29.3.178511

Bar-On, R. (1997). EQ-i, Bar-On Emotional Quotient Inventory: A measure of emotional intelligence (Technical manual). Toronto: Multi-Health Systems.

Bartlett, M. S. (1950). Tests of significance in factor analysis. British Journal of Statistical Psychology, 3(2), 77-85.

Butler, C., \& Chinowsky, P. (2006). Emotional intelligence and leadership behavior in construction executives. Journal of Management in Engineering, 22(3), 119-125. http://dx.doi.org/10.1061/ (asce)0742-597x(2006)22:3(119)

Cartwright, S., \& Pappas, C. (2008). Emotional intelligence, its measurement and implications for the workplace. International Journal of Management Reviews, 10(2), 149-171. http://dx. doi.org/10.1111/j.1468-2370.2007.00220.x 
Carvalho, V. S., Guerrero, E., Chambel, M. J., \& González-Rico, P. (2016). Psychometric properties of WLEIS as a measure of emotional intelligence in the Portuguese and Spanish medical students. Evaluation and Program Planning, 58, 152-159. http:// dx.doi.org/10.1016/j.evalprogplan.2016.06.006

Cattell, R. B. (1966). The scree test for the number of factors. Multivariate Behavioral Research, 1(2), 245-276. http://dx.doi. org/10.1207/s15327906mbr0102_10

Cavelzani, A. S., Lee, I. A., Locatelli, V., Monti, G., \& Villamira, M. A. (2003). Emotional intelligence and tourist services: the tour operator as a mediator between tourists and residents. International Journal of Hospitality and Tourism Administration, 4(4), 1-24. http://dx.doi.org/10.1300/j149v04n04_01

Cooper, R., \& Sawaf, A. (1997). Executive EQ: Emotional intelligence in leadership and organizations. New York, NY: Grosset/ Putnam.

Cronbach, L. J. (1951). Coefficient alpha and the internal structure of tests. Psychometrika, 16(3), 297-334. http://dx.doi. org/10.1007/bf02310555

Dabke, D. (2016). Impact of leader's emotional intelligence and transformational behavior on perceived leadership effectiveness: A multiple source of view. Business Perspectives and Research, 4(1), 27-40. http://dx.doi.org/10.1177/2278533715605433

Davies, M., Stankov, L., \& Roberts, R. D. (1998). Emotional intelligence: In search of an elusive construct. Journal of Personality and Social Psychology, 75(4), 989-1015. http://dx.doi. org/10.1037//0022-3514.75.4.989

El Ghoudani, K., Pulido-Martos, M., \& Lopez-Zafra, E. (2018). Measuring emotional intelligence in Moroccan Arabic: the Wong and Law Emotional Intelligence Scale / Medidas de la inteligencia emocional en árabe marroquí: la Escala de Inteligencia Emocional de Wong y Law. Revista de Psicologia Social, 33(1), 174-194. http://dx.doi.org/10.1080/02134748.2017.1385243

Fisher, C. D., \& Ashkanasy, N. M. (2000). The emerging role of emotions in work life: An introduction. Journal of Organizational Behavior, 21(2), 123-129. http://dx.doi.org/10.1002/(SICI)10991379(200003)21:2<123::AID-JOB33>3.0.CO;2-8

Fukuda, E., Saklofske, D. H., Tamaoka, K., \& Lim, H. (2012). Factor Structure of the Korean Version of Wong and Law's Emotional Intelligence Scale. Assessment, 19(1), 3-7. http://dx.doi. org/10.1177/1073191111428863

Fullan, M. (2001). Leading in a culture of change. San Francisco, CA: Jossey-Bass.

Gardner, L., \& Stough, C. (2002). Examining the relationship between leadership and emotional intelligence in senior level managers. Leadership \& Organization Development Journal, 23(2), 68-78. http://dx.doi.org/10.1108/01437730210419198

George, D., \& Mallery, P. (2013). IBM SPSS Statistics 21 step by step: a simple guide and reference (13th ed.). Boston, MA: Pearson.

Goleman, D. (1996). Emotional intelligence: Why it can matter more than IQ. New York, NY: Bloomsbury Publishing.

Goleman, D., \& Boyatzis, R. (2008). Social Intelligence and the Biology of Leadership. Harvard Business Review, 86(9), 74-81.

Goonan, K., \& Stoltz, P. (2004). Leadership and management principles for outcomes-oriented organizations, Medical Care, 42(4), III-31-III-38. http://dx.doi.org/10.1097/01. $\mathrm{mlr} .0000120782 .03031 . \mathrm{b} 4$

Guttman, L. (1945). A basis for analyzing test-retest reliability. Psychometrika, 10(4), 225-282. http://dx.doi.org/10.1007/ bf02288892

Hogan, R., \& Kaiser, R. (2005). What we know about leadership. Review of General Psychology, 9(2), 169-180. http://dx.doi. org/10.1037/1089-2680.9.2.169

Horn, J. L. (1965). A rationale and test for the number of factors in factor analysis. Psychometrika, 30(2), 179-185. http://dx.doi. org/10.1007/bf02289447

Hoyt, C. (1941). Test reliability estimated by analysis of variance. Psychometrika, 6(3), 153-160. http://dx.doi.org/10.1007/ bf02289270
Hu, L.T., \& Bentler, P.M. (1999). Cutoff criteria for fit indexes in covariance structure analysis: Conventional criteria versus new alternatives. Structural Equation Modeling, 6(1), 1-55. http:// dx.doi.org/10.1080/10705519909540118

Iliceto, P., \& Fino, E. (2017). The Italian version of the Wong-Law Emotional Intelligence Scale (WLEIS-I): A second-order factor analysis. Personality and Individual Differences, 116, 274-280. http://dx.doi.org/10.1016/j.paid.2017.05.006

Jordan, P. J., Ashkanasy, N. M., Härtel, C. E. J., \& Hooper, G. S. (2002). Workgroup emotional intelligence: Scale development and relationship to team process effectiveness and goal focus. Human Resource Management Review, 12(2), 195-214. http:// dx.doi.org/10.1016/s1053-4822(02)00046-3

Kaiser, H. F. (1974). An index of factorial simplicity. Psychometrika, 39(1), 31-36. http://dx.doi.org/10.1007/bf02291575

Keith, T. Z. (2019). Multiple regression and beyond: An introduction to multiple regression and structural equation modeling (3rd ed.). New York, NY: Routledge.

Law, K. S., Wong, C. S., \& Song, L. (2004). The construct and criterion validity of emotional intelligence and its potential utility for management studies. Journal of Applied Psychology, 89(3), 483-496. http://dx.doi.org/10.1037/0021-9010.89.3.483

Leslie, J. B., \& Van Velsor, E. (1996). A look at derailment today: North America and Europe. Greensboro, NC: Center for Creative Leadership.

Li, T., Saklofske, D. H., Bowden, S. C., Yan, G., \& Fung, T. S. (2012). The measurement invariance of the Wong and Law Emotional Intelligence Scale (WLEIS) across three Chinese university student groups from Canada and China. Journal of Psychoeducational Assessment, 30(4), 439-452. http://dx.doi. org/10.1177/0734282912449449

Libbrecht, N., Beuckelaer, A. De, Lievens, F., \& Rockstuhl, T. (2014). Measurement Invariance of the Wong and Law Emotional Intelligence Scale Scores: Does the Measurement Structure Hold Across Far Eastern and European Countries? Applied Psychology, 63(2), 223-237. http://dx.doi.org/10.1111/j.14640597.2012.00513.x

Livingstone, H., Nadjiwon-Foster, M., \& Smithers, S. (2002). Emotional intelligence \& military leadership. Retrieved from https://pdfs.semanticscholar.org/2435/e040b829e6580e2bbc935ddf8034fb50a899.pdf

Mayer, J., \& Salovey, P. (1993). The intelligence of emotional intelligence. Intelligence, 17(4), 433-442. http://dx.doi. org/10.1016/0160-2896(93)90010-3

Mayer, J., \& Salovey, P. (1997). What is Emotional Intelligence? In P. Salovey \& D. J. Sluyter (Eds.), Emotional development and emotional intelligence (pp. 3-31). New York, NY: Basic Books. http://dx.doi.org/10.1037/t05047-000

Mayer, J., Salovey, P., \& Caruso, D. (2000). Models of emotional intelligence. In R. J. Stemberg (Ed.), Handbook of intelligence (pp. 396-420). New York, NY: Cambridge University Press. http://dx.doi.org/10.1017/cbo9780511807947.019

Merino Soto, C., Lunahuaná-Rosales, M., \& Pradhan, R. K. (2016). Validación estructural del Wong-Law Emotional Intelligence Scale (WLEIS): estudio preliminar en adultos. Liberabit, 22(1), 103-110. http://dx.doi.org/10.24265/liberabit.2016.v22n1.09

Nguyen, N. N., Nham, P. T., \& Takahashi, Y. (2019). Relationship between ability-based emotional intelligence, cognitive intelligence, and job performance. Sustainability, 11(8). http://dx. doi.org/10.3390/su11082299

Nunnally, J. C., \& Bernstein, I. J. (1994). Psychometric theory (3rd ed.). New York, NY: McGraw- Hill.

Pacheco, N. E., Rey, L., \& Sánchez-Álvarez, N. (2019). Validation of the Spanish version of the Wong law emotional intelligence scale (WLEIS-S). Psicothema, 31(1), 94-100. http://dx.doi. org/10.7334/psicothema2018.147

R Core Team. (2019). R: A language and environment for statistical computing. Viena: R Foundation for Statistical Computing. 
Revelle, W. (2018). Psych: Procedures for personality and psychological research ( $R$ package version 1.8.12) [Computer software]. Retrieved from https://cran.r-project.org/web/packages/psych

Rinker, T., W. \& Kurkiewicz, D. (2017). Pacman: Package management for $R$ (R package version 0.5.0) [Computer software]. Retrieved from https://cran.r-project.org/package=pacman

Rizzolatti, G., \& Craighero, L. (2004). The mirror-neuron system. Annual Review of Neuroscience, 27, 169-192. http://dx.doi. org/10.1146/annurev.neuro.27.070203.144230

Rosseel, Y. (2012, May). Lavaan: An R package for Structural Equation Modeling. Journal of Statistical Software, 48(2). Retrieved from https://www.jstatsoft.org

Salovey, P., \& Mayer, J. (1990). Emotional Intelligence. Imagination, Cognition \& Personality, 9(3), 185-211. http://dx.doi. org/10.2190/DUGG-P24E-52WK-6CDG

Sanchez-Burks, J., \& Huy, Q. (2009). Emotional aperture: The accurate recognition of collective emotions. Organization Science, 20(1), 22-34. http://dx.doi.org/10.1287/orsc.1070.0347

Schulte, M. J., Ree, M. J., \& Carretta, T. R. (2004). Emotional intelligence: Not much more than g and personality. Personality and Individual Differences, 37(5), 1059-1068. http://dx.doi. org/10.1016/j.paid.2003.11.014

Schumacker, R. E., \& Lomax, R. G. (2016). A beginner's guide to structural equation modeling (4th ed.). New York, NY: Routledge. Schwartz, N. (1990). Feelings as information: Informational and motivational functions of affective states. In E. T. Higgins \& R. M. Sorrentino (Eds.), Handbook of motivation and cognition: Foundations of social behavior (Vol. 2, pp. 527-561). New York, NY: The Guilford Press.

Smollan, R., \& Parry, K. (2011). Follower perceptions of the emotional intelligence of change leaders: A qualitative study. Leadership, 7(4), 435-462. http://dx.doi.org/10.1177/1742715011416890

Wickham, H. (2017). Tidyverse: Easily install and load the "tidyverse" (R package version 1.2.1) [Computer software]. Retrieved from https://cran.r-project.org/web/packages/tidyverse

Wong, C. S., \& Law, K. S. (2002). The effects of leader and follower emotional intelligence on performance and attitude: An exploratory study. Leadership Quarterly, 13(3), 243-274. http:// dx.doi.org/10.1016/s1048-9843(02)00099-1

Wong, C-S, Wong, P-M., \& Law, K. S. (2007). Evidence of the practical utility of Wong's emotional intelligence scale in Hong Kong and mainland China. Asia Pacific Journal of Management, 24(1), 43-60. http://dx.doi.org/10.1007/s10490-006-9024-1 